Article

\title{
Environmental Impact Assessment of a School Building in Iceland Using LCA-Including the Effect of Long Distance Transport of Materials
}

\author{
Nargessadat Emami *, Björn Marteinsson and Jukka Heinonen \\ School of Engineering and Natural Sciences/Faculty of Civil and Environmental Engineering, \\ University of Iceland, Reykjavik 101, Iceland; bjomar@hi.is (B.M.); heinonen@hi.is (J.H.) \\ * Correspondence: nae4@hi.is \\ Academic Editor: Manuel Duarte Pinheiro \\ Received: 23 August 2016; Accepted: 24 October 2016; Published: 1 November 2016
}

\begin{abstract}
Buildings are the key components of urban areas and society as a complex system. A life cycle assessment was applied to estimate the environmental impacts of the resources applied in the building envelope, floor slabs, and interior walls of the Vættaskóli-Engi building in Reykjavik, Iceland. The scope of this study included four modules of extraction and transportation of raw material to the manufacturing site, production of the construction materials, and transport to the building site, as described in the standard EN 15804. The total environmental effects of the school building in terms of global warming potential, ozone depletion potential, human toxicity, acidification, and eutrophication were calculated. The total global warming potential impact was equal to $255 \mathrm{~kg}$ of $\mathrm{CO}_{2}$ eq/sqm, which was low compared to previous studies and was due to the limited system boundary of the current study. The effect of long-distance overseas transport of materials was noticeable in terms of acidification (25\%) and eutrophication (31\%) while it was negligible in other impact groups. The results also concluded that producing the cement in Iceland caused less environmental impact in all five impact categories compared to the case in which the cement was imported from Germany. The major contribution of this work is that the environmental impacts of different plans for domestic production or import of construction materials to Iceland can be precisely assessed in order to identify effective measures to move towards a sustainable built environment in Iceland, and also to provide consistent insights for stakeholders.
\end{abstract}

Keywords: buildings; construction materials; environmental impacts assessment; LCA; transportation

\section{Introduction}

The building and construction sectors are key sectors for sustainable development. While the building industry generates $5 \%$ to $15 \%$ of the global GDP, the built environment is responsible for one-third of the total final energy use and half of worldwide electricity consumption, as well as one-third of global carbon emissions [1,2]. According to the latest IPCC report [3], the energy use and related emissions from buildings can double or possibly even triple until 2050 as a result of several key trends, including growth in population, relocation to urban areas, changes in family size, rising levels of affluence, and behavioral changes.

Already, preventing emissions of GHGs by reducing the operational energy use in current buildings is of the utmost importance for policymakers in Europe. Thus, the main focuses of the European Performance Building Directive (EPBD) 2010/31/EU [4], and the Energy Efficiency Directive (2012/27/EU) [5] were to concentrate efforts towards better insulation, more efficient HVAC systems, and more use of sustainable energy. In the review of Chastas et al. [6], the embodied energy in residential buildings, including traditional, passive, and nearly zero energy buildings (nZEB), 
regardless of the drop in the total life cycle energy, the results demonstrate a growing portion of embodied energy from traditional to nZEB that could reach up to $50 \%$. As a result of the continuous narrowing of the building regulations' requirements to reduce emission from the operation of buildings, the relative importance of embodied emissions is quickly increasing [7-9]. This is already the case for Iceland for which the operation of buildings uses almost entirely renewable energy sources. Besides, enhancement in the energy efficiency of buildings may also bring in the use of materials and energy systems that might possibly increase the embodied carbon [10,11]. Recent evidence actually depicts that it might not be so much increasing consumption which drives the growth in global emissions, but the required capital investment to accommodate rural-urban movement, that is, the construction materials [12], which currently are neglected in the majority of assessment schemes and mitigation policies.

Since the early 1990s, an increasing number of methods have been suggested to evaluate the environmental impacts of buildings. Life Cycle Assessment (LCA) is nowadays the dominant assessment method for the embodied impacts that measure the emissions, usage of natural resources, and effect on health that can be related to different products or services over their complete life cycle. It quantifies the interactions with the surroundings, whether they are inputs to the system - such as natural resources, land, and energy—or as an output of the considered system—for example emissions to air, water, and soil.

A handful of studies have shown that the relative importance of embodied energy and embodied carbon can also be high over the whole building life cycle. An investigation on the energy consumed in a low-energy building in Gothenburg, Sweden showed that the embodied energy in one family home was responsible for around $45 \%$ of the total energy needs over 50 years [13]. Rawlinson and Weight [14] suggest that the embodied energy in residential buildings is approximately equal to 10 times the annual operational energy use, while this ratio can be around 30 for complex commercial buildings in the UK. Later, the analysis by Sturgis and Roberts [15] illustrated that for some building types, up to $62 \%$ of the whole life-cycle carbon may be due to embodied carbon emissions. On the other hand, Rossi, et al. [16] used a simple tool (validated with the certified software Equer) and estimated that the embodied carbon accounts for only $10 \%-20 \%$ of the total carbon emissions over the life cycle of the house. To assess the mitigation capacity of alternative materials, several studies have compared the embodied energy and environmental impact of alternative materials [17-21]. For example, Utama, et al. [21] evaluated the embodied GWP impacts of using traditional clay instead of concrete in houses in Indonesia. They estimated that substitution of concrete with traditional clay could reduce the GWP impacts by 9 million tons of $\mathrm{CO}_{2}$ eq by 2030. There are a number of studies that have concentrated on the embodied energy and the corresponding global warming potentials (GWP) (see for example [22]), but significantly fewer have included other impact categories (such as the ozone depletion potential, ODP; the acidification potential, AP; the eutrophication potential, EP; the photochemical ozone creation potential, POCP; etc.) $[23,24]$. Yet, they have suggested that the materials are an important source of several impacts. For example, Blengini, et al. [25] developed a detailed LCA over several impact categories including GWP, ODP, AP, EP, and POCP for a house located in Morozzo, Italy. The analysis has emphasized that, when addressing the performance of low-energy buildings, it is vital to account for the contribution of all life cycle phases and subsystems. In 2012, Passer et al. [26] analyzed the influence of five residential buildings in Austria on seven environmental indicators (AP, EP, GWP, ODP, $\mathrm{POCP}$, cumulative energy demand-non-renewable, CEDnr; cumulative energy demand-renewable, CEDr). This analysis indicates that although the operation phase is the most dominant phase in all impact categories, still, the contribution of impacts may differ considerably for construction products and the operation phase in many categories.

Recently, Soust-Verdaguer et al. [27] reviewed 20 case studies primarily in order to compare system boundary definitions, sources of information, the selected life cycle phases, and estimated environmental impact categories focusing on simplification approaches (read [28] for further elaboration) and secondly, to promote further developments on LCA. Heinonen et al. [29] also recently 
depicted how GWP cannot be used as an indicator for the majority of the environmental impact categories in the context of the embodied emissions in the building and construction sector.

The main contributions of this study to embodied emissions literature in the building sector are two-fold: First, five impact categories are assessed in this analysis. Besides, the results for different materials in different impact categories are clarified, which has been rare. Second, this work performs a comparative analysis focusing on the impacts from the place of material production and transportation, since the vast majority of all construction materials are imported to Iceland, putting a higher emphasis on transport than normal. Iceland has a unique position, considering the fact that it has significant hydro and geothermal resources, which emphasizes the role of imported embodied emissions. The renewable energy system means also that in many cases the local production of materials would reduce the emissions significantly. Domestic building materials are essentially only various types of fill, stone wool (and cement until 2012). The renewable-based energy system is actually the main reason why there has been relatively limited consideration for directives or guidelines for energy use in buildings in comparison to the other Nordic or European countries. Recently, there has been a shift towards a broader view of sustainable buildings in Iceland. The government demanded that all new state buildings need to be certified by BREEAM or other comparable certification schemes. More recently, the Icelandic Green Building Council (IGBC) is intended to explore the potentials of executing DGNB (German Scheme) in Iceland [30,31].

The object of this study was the 20-year-old Vættaskóli-Engi school building in Reykjavik, Iceland. The environmental impact of the materials employed in the school building in terms of GWP, ODP, HT, $\mathrm{AP}$, and EP were assessed with special attention to the transport of imported materials. The impact categories were selected to represent major environmental impacts. In addition, emissions from transportation to the construction site were estimated.

Section 2 presents the general framework of process LCA, while the case building and assessment method are described in Section 3. The assessment results are presented in Section 4, and Section 5 concentrates on the discussion of the results and a review of the uncertainties related to the study.

\section{Research Method}

The LCA approach to compute environmental effects is exemplified by the International Organization for Standardization (ISO) 14040 series. LCA is characterized as a framework which permits the formation of objective criteria and plans for the environmental impact evaluation of products (e.g., emission), considering the total life cycle (from cradle to grave) of the product. Based on ISO 14040, LCA is specified as the "collection and assessment of the inputs and outputs and the potential environmental impacts of a product or a system during its lifetime".

Eminent documents in this field are ISO 14040:2006 focusing on LCA principles and framework and ISO 14044:2006 with more emphasis on the key requirements and practical guidelines [32,33], which together form essential concepts necessary for developing a procedure to perform an LCA study.

The ISO standards allocate the LCA framework into four steps: goal and scope, inventory analysis, impact assessment and interpretation [33].

- Goal and scope outlines the envisioned application, the motivations for conducting a study, defines the methodological framework to satisfy the intended goals, outlines the boundary of the system and defines impact assessment methodology [33].

- Inventory analysis captures all inputs and all outputs that cross the selected system boundary.

- The Life Cycle Impact Assessment (LCIA) recognizes and estimates the extent and importance of the environmental impacts. Several methods are available [31], of which the most popular include:

The CML 2002 LCA Handbook [34], a follow-up of the CML 1992 [35] which defines he best practice for midpoint indicators, based on the ISO 14040 series of Standards.

Eco-indicator 99 allows the calculation of single-point eco-indicator score that can support designers in decision-making [36]. 
- ReCiPe [37] combines Eco-indicator 99 and CML 2002 methods by integrating midpoint and endpoint approaches in a rational scheme. All impact categories have also been updated excluding ionizing radiation [38].

- Interpretation depicts the results of the inventory analysis and/or impact assessment to reach clear, defensible conclusions.

\section{Research Design}

The Vættaskóli-Engi school building is located in Reykjavik, Iceland, and it was chosen because (i) it is a typical building representative of the buildings in Iceland in terms of the architecture, construction technology, and basic material use; (ii) this choice enabled us to assess the environmental effects of construction materials as near as possible to the "as built" situation.

The school building has a gross floor area of 5000 square meters. The construction of the building began in 1996 and was commissioned in 1997. The school consists of two main buildings connected with by hallway; one of the main buildings has a basement and two floor levels, the other one is on one level. Foundations, outer walls, floors slabs, and roof slabs of the main buildings are of concrete and also part of the interior walls, though some of the interior walls are of lightweight gypsum. The outer walls are insulated on the outside, partly with the rendering/insulation system and partly with ventilated aluminum cladding. The roofs are built as upside down systems on concrete slabs. The central hallway has an insulated lightweight timber structure which is cladded on the outside with aluminum sheets. Windows and doors are of aluminum, with double glazed insulation glass panes. While the general LCA methodology according to the ISO 14040:2006 standard [33] was described in Section 2, this section defines the methodology used in this study.

\subsection{Goal and Scope Definition}

The main objective of this study was to examine the environmental impacts of materials used (including the manufacturing and transportation) in the structure and envelope of the school building located in Reykjavik, Iceland. To account for major environmental concerns, a set of five impact categories were evaluated: global warming potential (GWP), ozone depletion potential (ODP), human toxicity (HT), acidification (AP), and eutrophication (EP). While there is a clear benefit from reporting the non-renewable energy use, due to lack of information regarding the use of non-renewable energies used for the production of imported materials, the impacts on non-renewable energy sources are not reported in this study. Two functional units were utilized: the entire school building and one square meter gross floor area of the school building.

The European Commission suggested the International Reference Life Cycle Data System (ILCD) as the official modelling guideline. Thus, the impact categories were assessed using the ILCD method, which is fully described in the Life Cycle Assessment handbook [39] and International Reference Life Cycle Data System (ILCD) handbook [40].

\subsection{System Boundaries}

Figure 1 illustrates the life cycle stages defined in the standard EN 15804 [41] and the green line shows the system boundary of this study which includes four modules of A1-A4: extraction of raw materials (A1); delivery to manufacturing site (A2); fabrication of construction materials (A3); and transportation to the construction site (A4), and thus all the embodied emissions except for from the construction site activities. The analysis covered the materials utilized in the structure and the envelope of the school building (foundation, beams and columns, floor slabs, exterior and interior walls, roofs, windows, and paint). Surface materials, fixture, fittings, stone filling material in the foundation, electrical and heating systems, and plumbing were excluded from this analysis. It should be noted that due to the scope of the study being cradle-to-grave (A1-A4), the lifespans of different 
materials and items are not entered in the assessment in the way they do in assessments over the whole life cycle of a building.

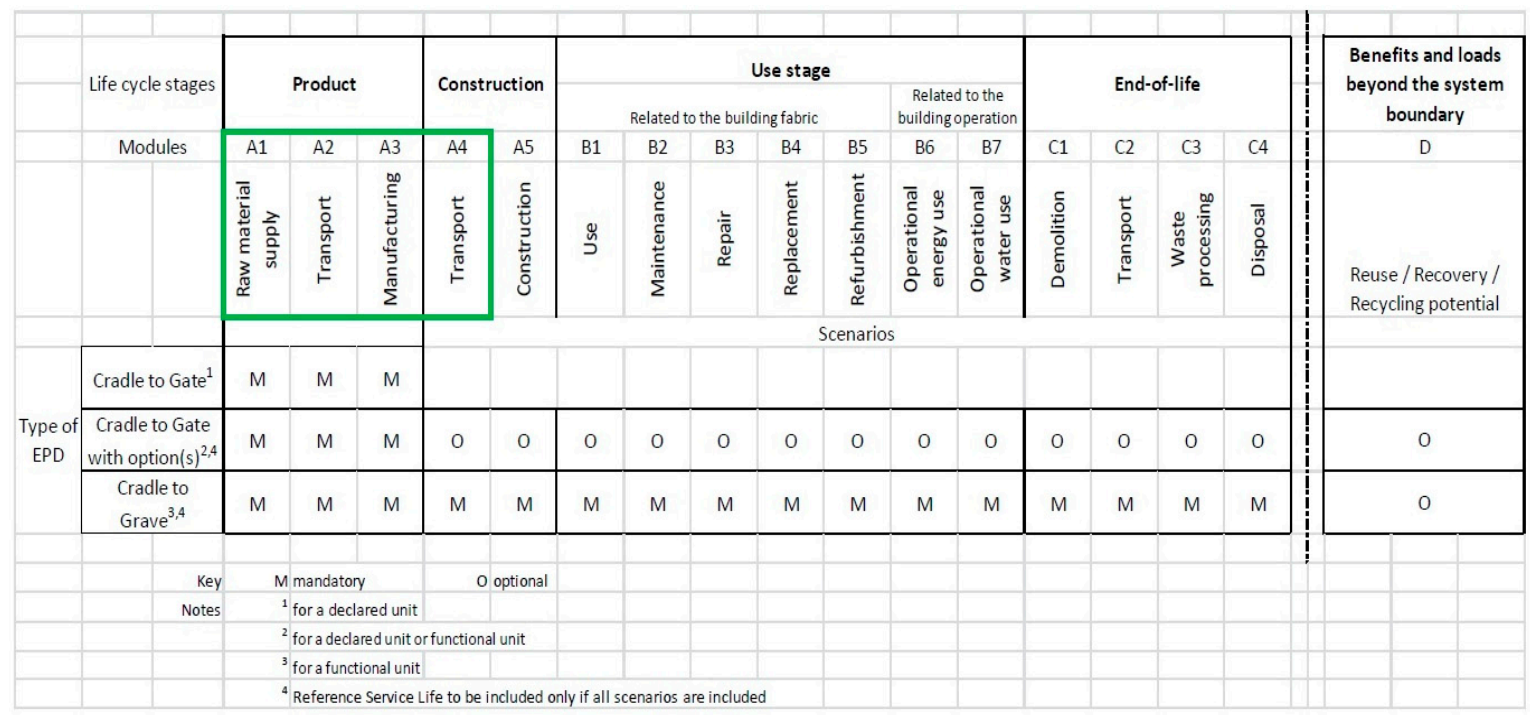

Figure 1. Life cycle stages according to the standard EN 15804 and boundary setting of this study.

\subsection{Inventory}

Currently, about $95 \%$ of buildings in Iceland are built of reinforced concrete. Cement as the central component of concrete was locally produced until 2012, whereas gravel and sand are available in abundance in Iceland. Besides, stone wool insulation is produced in Iceland, while nearly $79 \%$ of the required raw materials by weight are domestic, and the needed electricity is almost entirely generated by hydropower. Other building materials such as lumber, reinforcing steel, metal claddings, structural steel, aluminum window frames, window glass, raw materials for paints, as well as electrical and plumbing materials are imported from different European countries, China, Canada, and the US.

The life-cycle inventory data for analysis were taken from various sources, including the tender documents, drawings, descriptions, and quantity estimates. Table 1 presents a list of materials within the study scope, with the details of the estimated amount and information regarding where the materials are produced. The total weight of building materials for the scope of the school building was around 1.3 tons per one square meter of gross floor area. As expected, the biggest part was due to concrete, which represents $85 \%$ of the total weight of the building.

Table 1. Inventory data for building materials used in the school based on the tender documents.

\begin{tabular}{|c|c|c|c|c|}
\hline Building Materials & Quantities & Unit & Density $\left(\mathrm{kg} / \mathrm{m}^{3}\right)$ & Export Country \\
\hline Reinforcing steel & $175,000.0$ & $\mathrm{~kg}$ & & Lithuania \\
\hline Reinforcing mat & $17,197.8$ & $\mathrm{~kg}$ & & Lithuania \\
\hline Concrete & 2505.0 & $\mathrm{~m}^{3}$ & 2278 & Iceland \\
\hline Glued laminated timber & 15.42 & $\mathrm{~m}^{3}$ & 515 & Norway \\
\hline Corrugated steel cladding & 2820 & $\mathrm{~m}^{2}$ & 7850 & Finland \\
\hline Insulation, hard pressed stone wool & 12.3 & $\mathrm{~m}^{3}$ & 100 & Iceland \\
\hline Insulation, hard pressed stone wool & 306.8 & $\mathrm{~m}^{3}$ & 80 & Iceland \\
\hline Insulation lightweight stone wool & 234.4 & $\mathrm{~m}^{3}$ & 32 & Iceland \\
\hline Polyethylene, high density & 575 & $\mathrm{~m}^{2}$ & 950 & Germany \\
\hline Gypsum plaster board & 8908.0 & $\mathrm{~m}^{2}$ & 800 & Denmark \\
\hline Aluminum window & 625 & $\mathrm{~m}^{2}$ & & Germany \\
\hline
\end{tabular}


Table 1. Cont.

\begin{tabular}{ccccc}
\hline Building Materials & Quantities & Unit & Density $\mathbf{( k g / \mathbf { m } ^ { \mathbf { 3 } } )}$ & Export Country \\
\hline Expanded Polystyrene & 210.0 & $\mathrm{~m}^{2}$ & 25 & Germany \\
Extruded polystyrene & 400.5 & $\mathrm{~m}^{3}$ & 32 & Germany \\
Underroof membrane & 2670.0 & $\mathrm{~m}^{2}$ & & Germany \\
Plywood board & 13.4 & $\mathrm{~m}^{3}$ & 575 & Finland \\
Built-up asphalt & 3845.0 & $\mathrm{~m}^{2}$ & & Denmark \\
Concrete roofing tile & 131.8 & $\mathrm{~m}^{3}$ & 2100 & Iceland \\
Plaster & 148.6 & $\mathrm{~m}^{3}$ & 2000 & Iceland \\
Paint & 2.1 & $\mathrm{~m}^{3}$ & 1350 & Norway \\
\hline
\end{tabular}

The widely used LCA program GaBi 6.0 was utilized in the study. For most materials, the processes available in GaBi were utilized, but for locally produced materials, concrete and stone wool, new inventories were done with local data. Tables 2 and 3 present the inventory data for concrete and stone wool production in Iceland, respectively.

Table 2. Inventory data and embodied energy for $1 \mathrm{~kg}$ concrete production in Iceland—source: [42].

\begin{tabular}{cccc}
\hline Flow & Amount & Unit & Embodied Energy (MJ/kg) \\
\hline Cement (CEM I 32.5) & 0.1334 & $\mathrm{~kg}$ & 3.4 \\
Sand & 0.3781 & $\mathrm{~kg}$ & 0.0379 \\
Gravel & 0.4092 & $\mathrm{~kg}$ & 0.0422 \\
Concrete admixtures-plasticizer & 0.0013 & $\mathrm{Kg}$ & 30 \\
Water & 0.0780 & $\mathrm{Kg}$ & - \\
Electricity (Hydropower) & $8.90 \times 10^{-6}$ & $\mathrm{MJ}$ & $8.90 \times 10^{-6}$ \\
\hline
\end{tabular}

Icelandic stone wool is mainly made of local basalt sand and crushed sea shells (for $\mathrm{CaO}$ ), including the insignificant volume of dust binding oil and other elements. The inventory data for the production of $1 \mathrm{~kg}$ of stone wool in Iceland are presented in Table 3 from [43]. Based on the collected information and similar to concrete, a separate module was developed in GaBi.

Table 3. Inventory data for $1 \mathrm{~kg}$ stone wool production in Iceland-source: [43].

\begin{tabular}{ccc}
\hline Flow & Amount & Unit \\
\hline Electricity [hydro power] & 7.92 & $\mathrm{MJ}$ \\
Gravel (2/32) [Minerals] & 0.82 & $\mathrm{~kg}$ \\
Sea shell sand & 0.22 & $\mathrm{~kg}$ \\
Olivine [Non-renewable resources] & 0.10 & $\mathrm{~kg}$ \\
Aluminum oxide (alumina) [Inorganic intermediate products] & 0.05 & $\mathrm{~kg}$ \\
Phenol (hydroxyl benzene) [Organic intermediate products] & 0.05 & $\mathrm{~kg}$ \\
Three-Layer panels [Parts from renewable materials] (Package) & 0.04 & $\mathrm{~kg}$ \\
Plastic profile [Plastics] (Package) & 0.015 & $\mathrm{~kg}$ \\
Urea formaldehyde resin in-situ foam [Plastics] & 0.008 & $\mathrm{~kg}$ \\
Ammonia [Inorganic intermediate products] & 0.007 & $\mathrm{~kg}$ \\
\hline
\end{tabular}

\subsection{Impact Assessment}

The GaBi LCA program was used to estimate environmental impacts from construction materials. In this software, the impact factors are estimated based on models that are developed according to ILCD recommendations. In an earlier study, the authors developed two models in GaBi 6.0 for the production of concrete and stone wool in Iceland. For further information on the developed model, please read [44]. The impact factors for the rest of construction materials are obtained from GaBi's databases, except for aluminum windows, reinforcing steel, and alkyd paint where the information from the database in SimaPro was used. Both of these databases are compliant with ILCD recommendations. 
Regarding environmental impacts from transportation needed from the source country to Iceland and from seaport to the construction site (the standard EN 15804 phase A4), Breiðfjörð [45] have estimated the GWP impact from containerships to be $0.0327 \mathrm{~kg}$ of $\mathrm{CO}_{2} \mathrm{eq} / \mathrm{ton} \cdot \mathrm{km}$, while the value in $\mathrm{GaBi} 6.0$ is $0.0143 \mathrm{~kg} \mathrm{CO}$ eq/ton $\cdot \mathrm{km}$. It means that GHG emissions are more than double, which is due to the effect of heavy wind, big waves, and generally the difficulty of shipping route to Iceland. Therefore, it was decided to use the modified emission factor for the GWP impact from containership in Iceland. In order to modify the emission factors for other impact categories reported in GaBi, these factors are multiplied by the same ratio (2.28), which represents the difficulty of shipping to Iceland.

\section{Results}

The GHG emissions within the scope of the study of the school building were estimated at 1275 tons of $\mathrm{CO}_{2}$ eq for the whole building, meaning $255 \mathrm{~kg} \mathrm{CO}$ eq $/ \mathrm{m}^{2}$ gross floor area. Overseas transportation, despite the long distances, was only responsible for around $5 \%$ of the emissions. However, the past situation of cement being locally produced reduces especially the GHGs by $14.5 \mathrm{~kg}$ $\mathrm{CO}_{2} \mathrm{eq} / \mathrm{m}^{2}$ (depending on the import assumption) in comparison to the current state of its being imported. The emissions in the other impact categories are reported below. Within some of them, transportation has a very significant impact even without cement imports, but since the impacts are not normalized, the interpretation should be carried out carefully. Of the locally produced materials, the nearly carbon-free electricity system significantly benefits rock wool, but not concrete due to the limited amount of electricity used in cement and concrete production.

\subsection{Overall Environmental Impacts}

Table 4 indicates the overall environmental impacts and per one square meter of gross floor area impact of construction materials utilized for the structure of the school building on GWP, ODP, HT, AP, and EP.

Table 4. The results of total environmental impacts and per one sqm gross floor area impact of the school building by impact categories.

\begin{tabular}{|c|c|c|}
\hline Impacts Categories & Total Impacts & Total Impacts per One Sqm \\
\hline Global warming potential (GWP) & 1275 ton $\mathrm{CO}_{2}$ eq & $255 \mathrm{kgCO}_{2} \mathrm{eq}$ \\
\hline Ozone depletion potential (ODP) & $6.80 \times 10^{-3} \mathrm{~kg} \mathrm{CFC} 11 \mathrm{eq}$ & $1.36 \times 10^{-6} \mathrm{~kg} \mathrm{CFC} 11 \mathrm{eq}$ \\
\hline Human toxicity $(\mathrm{HT})$ & 0.16 CTUh & $3.23 \times 10^{-5}$ CTUh \\
\hline Acidification (AP) & 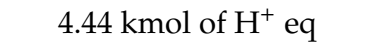 & 0.88 Mole of $\mathrm{H}^{+}$eq \\
\hline Eutrophication (EP) & $11.44 \mathrm{kmol}$ of $\mathrm{N}$ eq & 2.28 Mole of $\mathrm{N} \mathrm{eq}$ \\
\hline
\end{tabular}

The contributions of construction materials to environmental impacts including GWP, ODP, HT, $\mathrm{AP}$, and EP are compared in Figure 2. These show interesting differences, and depict how use of several materials must be concentrated to reduce the impacts through all the categories.

Concrete, reinforcing steel, and aluminum windows represent $51 \%, 21 \%$, and $9 \%$ of total GWP impact from school building, respectively. It should be noted that cement is one of the main component of concrete, and it represents over $95 \%$ of total $\mathrm{CO}_{2}$ emission from concrete. Reinforcing steel is the major contributor for ODP, HT, AP, and AP impacts, accounting for $34 \%, 30 \%, 35 \%$, and $33 \%$ of total ODP, HT, AP, and AP impacts, respectively. Regarding the ODP impact, the contribution of concrete seems to be negligible. However, when comparing the ODP intensities between GaBi and SimaPro databases, it appears that the impact factors per $1 \mathrm{~kg}$ of concrete in $\mathrm{GaBi}$ and SimaPro are significantly different, $1.74 \times 10^{-12}$ and $3.71 \times 10^{-9}$, respectively. The reasons for the difference should be studied further, however, to draw further conclusions.

Table 5 below presents the estimated environmental impacts based on the developed model for $1 \mathrm{~kg}$ of concrete and $1 \mathrm{~kg}$ of stone wool which are produced in Iceland. It should be noted that the scope of these models includes A1-A3 modules. 


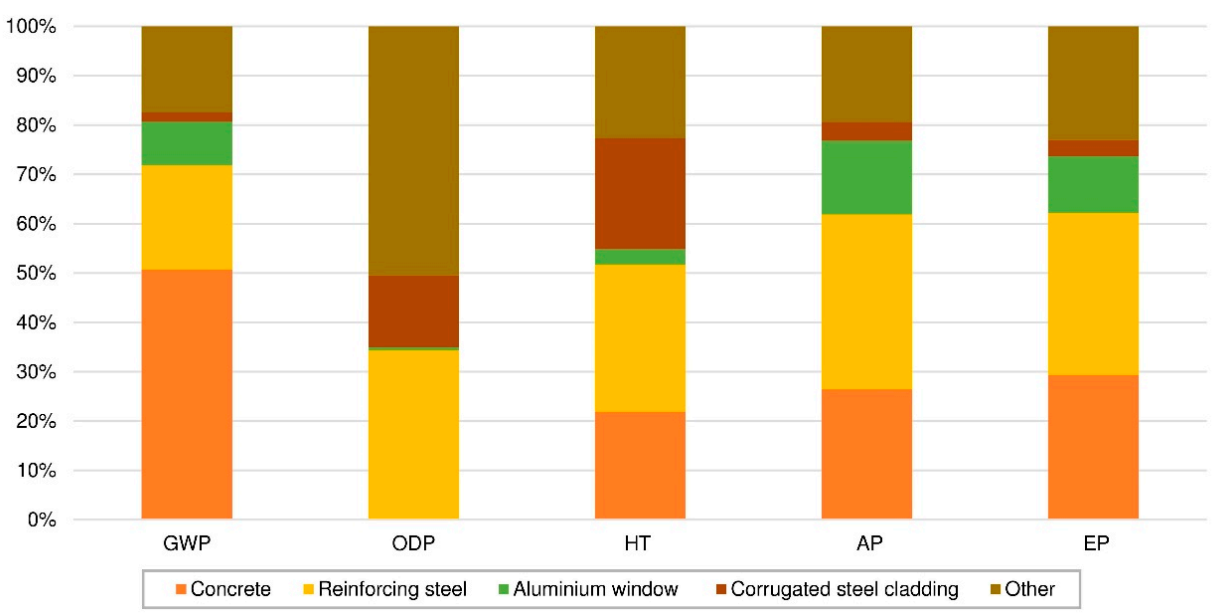

Figure 2. Total environmental impacts for modules A1-A4 by construction materials used in the school building. (The group of "Other" includes paint, plywood board, underroof membrane, glulam, stone wool, HDPE, plaster, EPS, and XPS.)

Table 5. Total environmental impacts from concrete and stone wool produced in Iceland.

\begin{tabular}{cccccc}
\hline & $\begin{array}{c}\text { GWP } \\
\text { (kg CO } \mathbf{~} \text { eq.) }\end{array}$ & $\begin{array}{c}\text { ODP } \\
\text { (kg CFC 11 eq.) }\end{array}$ & $\begin{array}{c}\text { HT } \\
\text { (Mole of } \mathbf{H}^{+} \text {eq.) }\end{array}$ & AP (CTUh) & $\begin{array}{c}\text { EP } \\
\text { (Mole of N eq.) }\end{array}$ \\
\hline 1 kg of Concrete & $1.13 \times 10^{-1}$ & $1.74 \times 10^{-12}$ & $6.12 \times 10^{-9}$ & $2.03 \times 10^{-4}$ & $5.74 \times 10^{-4}$ \\
1 kg of Stone wool & $4.33 \times 10^{-1}$ & $1.33 \times 10^{-11}$ & $5.34 \times 10^{-8}$ & $1.05 \times 10^{-3}$ & $3.45 \times 10^{-3}$ \\
\hline
\end{tabular}

To validate the GWP impact estimates for stone wool, Figure 3 illustrates the comparison between the calculated GWP impact of $1 \mathrm{~kg}$ of stone wool produced in Iceland, with the findings for UK (obtained from [46]), Average EU (estimated by experts at Steinull company [47]), and Germany (obtained from GaBi 6.0 database [48]). According of Figure 3, the GWP impact of stone wool produced in Iceland $\left(0.433 \mathrm{~kg} \mathrm{CO}_{2} \mathrm{eq}\right.$ ) is much lower (around $41 \%$ ) compared to the EU average. This difference was due to the significant use of environmentally friendly hydropower electricity in the stone wool production process in Iceland, compared to the average for the EU, UK, and Germany. The overall impact of the locally produced stone wool in the building studied was low, however. According to our estimates, stone wool accounted for $1.18 \%, 0.01 \%, 1.18 \%, 0.88 \%$, and $1.20 \%$ of total GWP, ODP, HT, AP, and AP impacts, respectively.

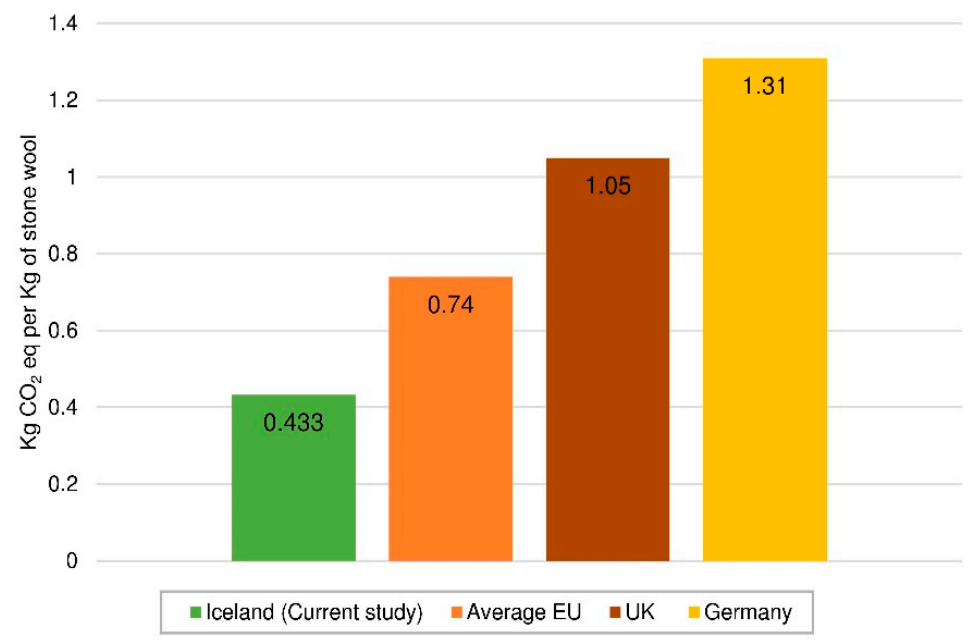

Figure 3. Comparison of GWP impact per $1 \mathrm{~kg}$ of stone wool. 


\subsection{Transportation}

According to our assessment, transportation was responsible for $25 \%$ and $31 \%$ of the total AP and EP impacts, respectively, while the impact of transportation on other impact categories were relatively small ( $5 \%$ or less). Only a one-way trip was included as the vessel needs to be used for exports from Iceland on the route back. To better understand the benefits of domestic construction materials in Iceland and also to capture the impact of transportation on selected environmental categories, two cases were compared for concrete production. In the base case, the cement was produced in Iceland and in the second case, it was imported from Germany.

Figure 4 demonstrates that producing the cement in Iceland caused less environmental impacts in all five impact categories compared to the case in which the cement is imported from Germany. The total environmental impacts of the Vættaskóli-Engi school would increase by $5.7 \%$ and $2.5 \%$ in terms of GWP and HT, subsequently, if concrete was imported, while there would be no significant changes in terms of the ODP impact. Moreover, a substantial rise (more than 50\%) was noticeable in terms of overall AP and EP. The additional impacts were all due to the transportation of cement, while other ingredients for concrete were domestic.

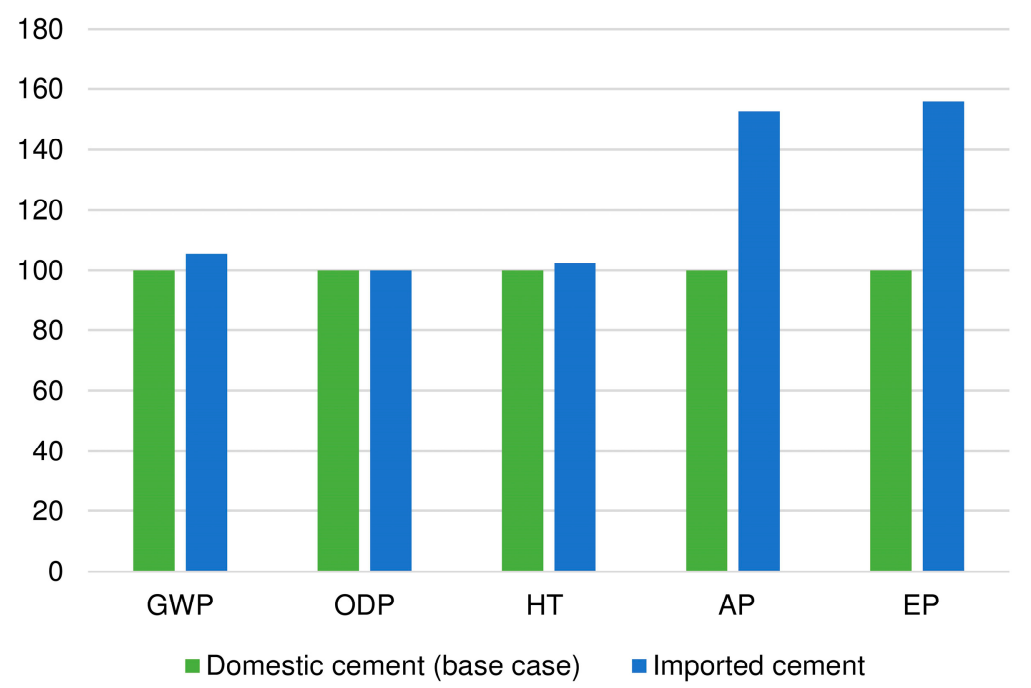

Figure 4. Normalized comparison of the total environmental impacts from two cases for concrete production; Base $=100$ for cement produced in Iceland, Imported cement: cement imported from Germany.

\subsection{Inter-Study Comparison of the GWP Impact Assessment}

In order to compare the findings and position the study among the previous literature, the estimated GWP impact per one square meter of gross floor area from A1-A4 modules was compared with selected previous studies (Figure 5). It is challenging to compare one LCA study to another, even when a similar process LCA approach is adopted, mainly because of inherent boundary issues with LCA studies. Thus, the system boundaries of previous studies are briefly discussed here. A decision to limit the comparison analysis to the GWP category was made to bring up the main issues, which then apply very similarly to other categories. It has been depicted by Herrmann and Moltesen [49] that even the most widely utilized LCA software can lead to different outcomes, but studying this uncertainty was out of reach in this study, and the general uncertainties are still the same.

Figure 5, compares GWP impacts of the Vættaskóli-Engi school building per square meter of gross floor area with similar LCA studies. The impacts were grouped based on construction materials and modules as defined in EN 15804 [41]. As depicted by the figure, the estimated GWP per one square meter of Vættaskóli-Engi school building was about $54 \%-83 \%$ of the others, but similar to the impacts from "A1-A3 (Concrete)" and "A1-A3 (Steel)" together. This, to a large extent, depicts the different 
boundaries regarding the category "A1-A3 (Other)". The difference points out that the scope of this work is limited compared to the other case studies.

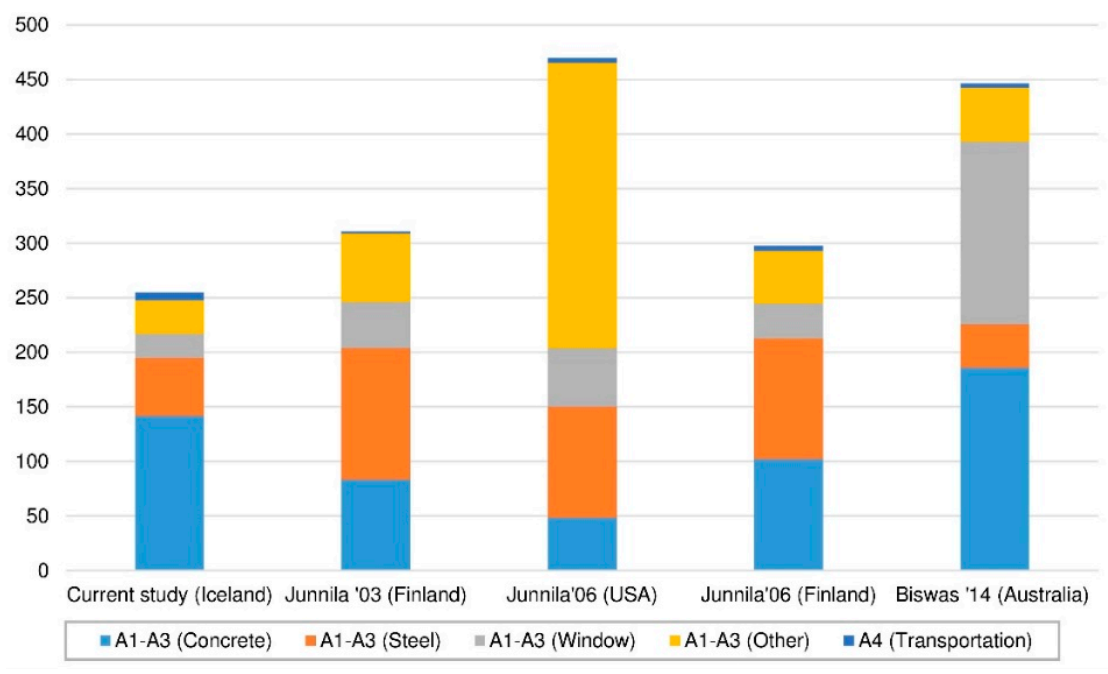

Figure 5. Compares the GWP impact of the Vættaskóli-Engi school building per square meter of gross floor area with similar LCA studies. The impacts are grouped based on construction materials and modules as defined in EN 15804.

In all cases, concrete and steel accounted for a significant share of total GWP, ranging from 10\% to $56 \%$ for concrete and $9 \%$ to $39 \%$ for steel. This is also fully consistent with the finding of [29] that materials that are in terms of weight considered unimportant, those often left outside the assessment scopes, can have significant overall impact even in the GWP category, and much more so in other categories. If estimating according to the results of Heinonen et al. [29], the magnitude of the cutoffs in this study due to the boundary selection was $20 \%-25 \%$ in GWP. It is thus important to interpret the results correctly and to compare the overall levels of the results in different categories to studies with wider scopes. Another observation was that the contribution of steel in the GWP impact was higher than concrete in [50,51], while it was significantly lower in the Biswas' work [52] and the current study. Since the buildings assessed in $[50,51]$ have four and five floors, and considering the dominance of steel in multi-story buildings [53], as expected, the contribution of steel on the GWP impact was higher than in the current study.

In process LCAs, such as this study, another important uncertainty perspective is brought about by the inherent truncation error related to the comprehensiveness of the processes included to the LCA databases [54,55]. The processes are almost always imperfect, truncated, and the capital requirements often fully or partially not included. According to [56], the other main LCA approach, the input-output (IO) LCA, can often lead to 10s of percentages higher calculations because of this type of an error (or bias), not affecting IO LCAs. The magnitude of the truncation error cannot be easily quantified in a particular study, but it is obvious that the highest per $\mathrm{m}^{2}$ embodied emissions in building LCAs have been suggested in IO LCA studies $[7,57,58]$. This issue thus further highlights the importance of the one interpreting and using LCA results to require both LCA knowledge and knowledge about the particular study at hand.

Finally, of the aspects included in this validation analysis, several choices within an LCA about recycling rates, end of life treatment of materials, and other issues can lead to important differences. Recycling potential in the end of life can be counted as a credit even affecting the results significantly. The carbon sink capability of wooden products can be calculated as well as the carbonization of concrete, again affecting the results and making comparisons of different studies difficult without detailed knowledge about LCA and the studies to be compared. 


\section{Discussion and Conclusions}

The purpose of this study was to measure the environmental impacts from construction materials used in the Vættaskóli-Engi school building, focusing on the influence of the source of materials (locally produced vs. imported). The contributions of the study to the building pre-use LCA literature are twofold: First, this study includes the five most widely utilized impact categories of GWP, ODP, HT, AP, and EP. Furthermore, the results are reported for different materials in the different impact categories. Thus the current study provides a point of reference on that level for future studies. The second contribution relates to two special conditions in Iceland: the high import rate of construction materials increases the importance of transport; the energy system in Iceland being fully based on renewable energy emphasizes the role of emissions embodied in the construction materials. Under these conditions, local production of materials could be a powerful measure to decrease the emissions significantly.

The scope of the study covers four pre-use phase modules of A1-A4 as designated in the standard EN 15804. Total impacts from the materials employed in the building for the selected scope of the study in terms of GWP, ODP, HT, AP, and EP were estimated to be 1275 ton $\mathrm{CO}_{2}$ eq, $0.0068 \mathrm{~kg}$ CFC 11 eq, $0.16 \mathrm{CTUh}, 4.44 \mathrm{kmol}$ of $\mathrm{H}^{+}$eq, $11.44 \mathrm{kmol}$ of $\mathrm{N}$ eq, respectively; which were calculated per square meter of gross floor area $255 \mathrm{kgCO}_{2} \mathrm{eq} / \mathrm{sqm}, 1.36 \times 10^{-6} \mathrm{~kg} \mathrm{CFC} 11 \mathrm{eq} / \mathrm{sqm}, 3.23 \times 10^{-5} \mathrm{CTUh} / \mathrm{sqm}$, $0.88 \mathrm{Mole}$ of $\mathrm{H}^{+} \mathrm{eq} / \mathrm{sqm}$, and 2.28 Mole of $\mathrm{N} \mathrm{eq} / \mathrm{sqm}$. As anticipated, concrete, reinforcing steel and aluminum windows were the main contributors and in total were responsible for $35 \%-81 \%$ of the overall assessed impacts. Based on the results of environmental assessment, reducing the usage of concrete and reinforcing steel would have high-yield results for the building's overall environmental impacts. The impact of transport was found to be the cause of only $5 \%$ of total GWP despite the very long transport distances, but gave a much higher impact for AP and EP. However, local production would still provide benefits in both transportation-related impacts and, due to the Icelandic low-carbon energy system, impacts currently outsourced to other countries, where the materials' production take place. Based on inter-study comparison in Figure 5, the results of this study are somewhat below those of the comparison cases, but similar in terms of concrete and steel, which corresponds to the limited system boundary of this study. Based on the estimated GWP impacts in [50,51], which have assessed multi-story buildings, and considering the dominance of steel in multi-story buildings [53], it was observed that higher use of steel in the structure of the building can significantly increase the overall GWP impacts of the building. Meanwhile, the ODP impact from concrete was found to be insignificant.

A significant difference was observed when comparing the ODP intensities between GaBi and SimaPro databases and further studies are required to draw further conclusions. Overall, the potential inconsistencies across the database information for the impacts of construction materials in different LCA tools would merit supplementary examination.

Considering the fact that most of the construction materials are imported to Iceland, a comparative analysis was done to assess the benefits of domestic construction materials in Iceland. As expected, it was concluded that producing the cement in Iceland caused less environmental impacts in all five impact categories compared to the case in which the cement is imported from Germany. If the concrete was imported, total environmental impacts of the school would rise by $5.7 \%$ and $2.5 \%$ in terms of GWP and HT, while there would be no significant differences in terms of ODP impact. Also, a considerable rise (more than 50\%) in terms of overall $\mathrm{AP}$ and $\mathrm{EP}$ would be expected. The additional impacts are all due to the transportation of cement to Iceland for concrete production.

Although this examination was carefully arranged, there are uncertainties associated with this study. First of all, it should be noted that, according to the boundary of the system defined for this study, only the environmental impacts of four modules (A1-A4) as described in the standard EN 15804 are assessed of the whole life cycle. To interpret the results, it should be considered that, surface materials, electric systems, and plumbing as well as the emissions from the manufacturing work, operation and end of life are not calculated in this analysis. AS mentioned, if assessed according to the cutoff estimations of [29] for GWP impact, the cutoff is $20 \%-25 \%$, but at least as important in other categories 
and up to $50 \%$ in HT. This draws attention to the correct interpretation of LCA results. In addition, considering the scope of the study (A1-A4), the lifespans of materials and components do not affect the assessment in the way they do in assessments over the whole life cycle of a building. Comparisons between different buildings among assessments limited to our scope could result in biased results if in some buildings materials with low initial impacts but short lifespans would dominate and in others materials with high initial impacts but long lifespans Utilization the results of a certain study should take into account the scope limitations, and even more so the utilized LCA method, as it is obvious that IO LCAs return significantly higher estimates than process LCAs [59].

Despite the recognized limitation in the developed model, this analysis has provided valuable insights regarding the embodied impacts of construction materials utilized in the structure of the school building. The identification of major contributors to each impact category is the first step to detect the most effective mitigation measure. In the following stage of this research, the data collection phase will be extended to enhance the accuracy of inventory dataset and minimize the uncertainty from imprecise input parameters.

Acknowledgments: The Authors thank Landsvirkjun (The National Power Company) for financing this work, Reykjavik municipality-Technical division for providing documentation and giving access to the building in question and acknowledge Professor Brynhildur Davíðsdóttir for providing access to a license of GaBi. We also thank the Academy of Finland (Grant 286747) for supporting the study.

Author Contributions: As the primary author, Nargessadat Emami initiated the study, performed the majority of the analysis, and wrote the main body of this paper. Björn Marteinsson supervised the study, contributed to process of data collection and provided advice on the research scope and methodology. Jukka Heinonen contributed in editing and structuring the paper and advising on data analysis.

Conflicts of Interest: The authors declare no conflict of interest. The founding sponsors had no role in the design of the study; in the collection, analyses, or interpretation of data; in the writing of the manuscript, and in the decision to publish the results.

\section{References}

1. International Energy Agency Publications (IEA). Transition to Sustainable Buildings-Strategies and Oppurtunities to 2050; International Energy Agency Publications: Paris, France, 2013.

2. Rode, P.; Burdett, R.; Soares, J.C. Buildings: Investing in energy and resource efficiency Book section. In Towards a Green Economy: Pathways to Sustainable Development and Poverty Eradication; United Nations Environment Programme: Washington, DC, USA, 2011; pp. 331-373.

3. Intergovernmental Panel on Climate Change (IPCC). Managing the Risks of Extreme Events and Disasters to Advance Climate Change Adaptation; Field, C.B., Barros, V., Stocker, T.F., Qin, D., Dokken, D.J., Ebi, K.L., Mastrandrea, M.D., Mach, K.J., Plattner, G.-K., Allen, S.K., et al., Eds.; Cambridge University Press: Cambridge, UK; New York, NY, USA, 2012.

4. The European Parliament and the Council of the European Union. Directive 2010/31/EU of the European Parliament and of the Council on the Energy Performance of Buildings (Recast); Official Journal of the European Union: Luxembourg, 2010; Volume 153, pp. 13-35.

5. The European Parliament and the Council of the European Union. Directive 2012/27/EU of the European Parliament and of the Council of 25 October 2012 on Energy Efficiency, Amending Directives 2009/125/EC and 2010/30/EU and Repealing Directives 2004/8/EC and 2006/32/EC; Official Journal of the European Union: Luxembourg, 2012.

6. Chastas, P.; Theodosiou, T.; Bikas, D. Embodied energy in residential buildings-towards the nearly zero energy building: A literature review. Build. Environ. 2016, 105, 267-282. [CrossRef]

7. Säynäjoki, A.; Heinonen, J.; Junnila, S. A scenario analysis of the life cycle greenhouse gas emissions of a new residential area. Environ. Res. Lett. 2012, 7, 034037. [CrossRef]

8. Isaksson, C.; Karlsson, F. Indoor climate in low-energy houses-an interdisciplinary investigation. Build. Environ. 2006, 41, 1678-1690. [CrossRef]

9. Karlsson, J.; Roos, A.; Karlsson, B. Building and climate influence on the balance temperature of buildings. Build. Environ. 2003, 38, 75-81. [CrossRef] 
10. Tingley, D.D.; Davison, B. Design for deconstruction and material reuse. Proc. Inst. Civ. Eng. 2011, 164, 195-204. [CrossRef]

11. Georgiadou, M. Future-Proofed Energy Design Approaches for Achieving Low-Energy Homes: Enhancing the Code for Sustainable Homes. Buildings 2014, 4, 488-519. [CrossRef]

12. Minx, J.C.; Baiocchi, G.; Peters, G.P.; Weber, C.L.; Guan, D.; Hubacek, K. A “Carbonizing Dragon”: China's Fast Growing $\mathrm{CO}_{2}$ Emissions Revisited. Environ. Sci. Technol. 2011, 45, 9144-9153. [CrossRef] [PubMed]

13. Thormark, C. A low energy building in a life cycle-Its embodied energy, energy need for operation and recycling potential. Build. Environ. 2002, 37, 429-435. [CrossRef]

14. Rawlinson, S.; Weight, D. Sustainability_Embodied carbon. Building 2007, 41, 88-91.

15. Sturgis, S.; Roberts, G. Redefining Zero: Carbon Profiling as a Solution to Whole Life Carbon Emission Measurement in Buildings; RICS Research: London, UK, 2010.

16. Rossi, B.; Marique, A.F.; Glaumann, M.; Reiter, S. Life-cycle assessment of residential buildings in three different European locations, basic tool. Build. Environ. 2012, 51, 395-401. [CrossRef]

17. Salcido, J.C.; Raheem, A.A.; Ravi, S. Comparison of embodied energy and environmental impact of alternative materials used in reticulated dome construction. Build. Environ. 2016, 96, 22-34. [CrossRef]

18. Morel, J.C.; Mesbah, A.; Oggero, M.; Walker, P. Building houses with local materials: Means to drastically reduce the environmental impact of construction. Build. Environ. 2001, 36, 1119-1126. [CrossRef]

19. González, M.J.; García Navarro, J. Assessment of the decrease of CO2 emissions in the construction field through the selection of materials: Practical case study of three houses of low environmental impact. Build. Environ. 2006, 41, 902-909. [CrossRef]

20. Thormark, C. The effect of material choice on the total energy need and recycling potential of a building. Build. Environ. 2006, 41, 1019-1026. [CrossRef]

21. Utama, N.A.; Mclellan, B.C.; Gheewala, S.H.; Ishihara, K.N. Embodied impacts of traditional clay versus modern concrete houses in a tropical regime. Build. Environ. 2012, 57, 362-369. [CrossRef]

22. Du, P.; Wood, A.; Stephens, B.; Song, X. Life-Cycle Energy Implications of Downtown High-Rise vs. Suburban Low-Rise Living: An Overview and Quantitative Case Study for Chicago. Buildings 2015, 5, 1003-1024. [CrossRef]

23. Khasreen, M.M.; Banfill, P.F.G.; Menzies, G.F. Life-Cycle Assessment and the Environmental Impact of Buildings: A Review. Sustainability 2009, 1, 674-701. [CrossRef]

24. Robertson, A.B.; Lam, F.C.F.; Cole, R.J. A Comparative Cradle-to-Gate Life Cycle Assessment of Mid-Rise Office Building Construction Alternatives: Laminated Timber or Reinforced Concrete. Buildings 2012, 2, 245-270. [CrossRef]

25. Blengini, G.A.; Di Carlo, T. Energy-saving policies and low-energy residential buildings: An LCA case study to support decision makers in piedmont (Italy). Int. J. Life Cycle Assess. 2010, 15, 652-665. [CrossRef]

26. Passer, A.; Kreiner, H.; Maydl, P. Assessment of the environmental performance of buildings: A critical evaluation of the influence of technical building equipment on residential buildings. Int. J. Life Cycle Assess. 2012, 17, 1116-1130. [CrossRef]

27. Soust-Verdaguer, B.; Llatas, C.; Garcia-Martinez, A. Simplification in life cycle assessment of single-family houses: A review of recent developments. Build. Environ. 2016, 103, 215-227. [CrossRef]

28. Kellenberger, D.; Althaus, H.J. Relevance of simplifications in LCA of building components. Build. Environ. 2009, 44, 818-825. [CrossRef]

29. Heinonen, J.; Säynäjoki, A.; Junnonen, J.-M.; Pöyry, A.; Junnila, S. Pre-use phase LCA of a multi-story residential building: Can greenhouse gas emissions be used as a more general environmental performance indicator? Build. Environ. 2016, 95, 116-125. [CrossRef]

30. Sand, H.; Hjorth, K.L.; Nittegaard, C.B. Survey of Green Legislation and Standards in the Construction Area in the Nordic Countries; Nordic Council of Ministers: Copenhagen, Denmark, 2012.

31. Vífilsdóttir, H.; Bjarnadóttir, H.J.; Kadmark, L.; Sigurðardóttir, K.; Jónsdóttir, S.B. Vistvottunarkerfi Fyrir Byggingar-Greining á Hagkvæmni og Aðlögunarhæfni Erlendra Vottunarkerfa Fyrir Íslenskan Byggingarmarkað, (Ecological Certification System for Architectural Analysis of the Efficiency and Adaptability of Foreign Certification System; Vistbyggðarráð: Reykjavik, Iceland, 2013.

32. IOS 14044 Environmental Management_Life Cycle Assessment: Requirements and Guidelines; International Organization for Standardization: Geneva, Switzerland, 2006. 
33. IOS 14040 Environmental Management_Life Cycle Assessment: Principles and Framework; International Organization for Standardization: Geneva, Switzerland, 2006.

34. Guinée, J.B.; Gorrée, M.; Heijungs, R.; Huppes, G.; Kleijn, R.; de Koning, A.; van Oers, L.; Wegener Sleeswijk, A.; Suh, S.; Udo de Haes, H.A.; et al. Handbook on Life cycle Assessment. Operational Guide to the ISO Standards. I: LCA in Perspective. IIa: Guide. IIb: Operational Annex. III: Scientific Background; Kluwer Academic Publishers: Dordrecht, The Netherlands, 2002.

35. Heijungs, R.; Guinée, J.; Huppes, G.; Lankreijer, R.M.; Udo de Haes, H.A.; Wegener Sleeswijk, A.; Ansems, A.M.M.; Eggels, P.G.; van Duin, R.; de Goede, H.P. Environmental Life Cycle Assessment of Products-Guide and Backgrounds; Institute of Environmental Sciences (CML): Leiden, The Netherlands, 1992.

36. Goedkoop, M.; Spriensma, R. The Eco-indicator 99-A Damage-Oriented Method for Life Cycle Impact Assessment; Methodology Report; Product Ecology Consultants: Amersfoort, The Netherlands, 2000.

37. Goedkoop, M.; Heijungs, R.; Huijbregts, M.; De Schryver, A.; Struijs, J.; ZelmR, V. ReCiPe 2008. A life Cycle Impact Assessment Method Which Comprises Harmonised Category Indicators at the Midpoint and the Endpoint Level; Rijksinstituut voor Volksgezondheid en Milieu: Bilthoven, The Netherlands, 2009.

38. De Schryver, A.M.; Brakkee, K.W.; Goedkoop, M.J.; Huijbregts, M.A.J. Characterization factors for global warming in life cycle assessment based on damages to humans and ecosystems. Environ. Sci. Technol. 2009, 43, 1689-1695. [CrossRef] [PubMed]

39. Curran, M.A. Life Cycle Assessment Handbook: A Guide for Environmentally Sustainable Products; John Wiley \& Sons.: New York, NY, USA, 2012.

40. European Conmmission JRC (EC-JRC). International Reference Life Cycle Data System (ILCD) Handbook-General Guide for Life Cycle Assessment_Detailed Guidance; European Conmmission JRC: Luxembourg, 2010.

41. EN 15804:2012+A1 Sustainability of Construction Works. Environmental Product Declarations. Core Rules for the Product Category of Construction Products; U.S. Green Building Council: Atlanta, GA, USA, 2012.

42. Marteinsson, B. Materials and energy use in buildings. In Proceedings of the 9th International Conference on Durability of Building Materials and Components, Brisbane, Australia, 17-21 March 2002.

43. Úlfarsson, S.O. Vistferilsgreining á Timbureiningahúsi frá Vöggu til Grafar (Life Cycle Assessment of a Timber House from Cradle to Grave); University of Iceland: Reykjavík, Iceland, 2011.

44. Emami, N. Environmental Impact Assessment of a School Building in Iceland Using Life Cycle Analysis; Case Study of the Vættaskóli-Engi Building; University of Iceland: Reykjavík, Iceland, 2016.

45. Breiðfjörð, K. Byggingarefni á Íslandi. Uppruni, Flutningar til Landsins Ásamt kolefnisspori Timburs (Building Materials in Iceland. Origin, Transportation to the Country Together with the Carbon Footprint of Timber); University of Iceland: Reykjavík, Iceland, 2011.

46. Hammond, G.P.; Jones, C.I. Embodied energy and carbon in construction materials. Proc. Inst. Civ. Eng. Energy 2008, 161, 87-98. [CrossRef]

47. Steinull H.F. Available online: http://steinull.is/mineral-fiber-insulation (accessed on 10 June 2016).

48. PE-International GaBi: Product Sustainability Software. Version 6.0. Available online: www.gabi-software.com/ (accessed on 15 February 2016).

49. Herrmann, I.T.; Moltesen, A. Does it matter which Life Cycle Assessment (LCA) tool you choose?-A comparative assessment of SimaPro and GaBi. J. Clean. Prod. 2015, 86, 163-169. [CrossRef]

50. Junnila, S.; Horvath, A. Life-Cycle Environmental Effects of an Office Building. J. Infrastruct. Syst. 2003, 9, 157-166. [CrossRef]

51. Junnila, S.; Horvath, A.; Guggemos, A.A. Life-Cycle Assessment of Office Buildings in Europe and the United States. J. Infrastruct. Syst. 2006, 12, 10-17. [CrossRef]

52. Biswas, W.K. Carbon footprint and embodied energy assessment of a civil works program in a residential estate of Western Australia. Int. J. Life Cycle Assess. 2014, 19, 732-744. [CrossRef]

53. BS EN 1994-1-1 Eurocode 4. Design of Composite Steel and Concrete Structures. General Rules and Rules for Buildings; The British Standards Institution (BIS): London, UK, 2004.

54. Suh, S.; Lenzen, M.; Treloar, G.J.; Hondo, H.; Horvath, A.; Huppes, G.; Jolliet, O.; Klann, U.; Krewitt, W.; Moriguchi, Y.; et al. System boundary selection in life-cycle inventories using hybrid approaches. Environ. Sci. Technol. 2004, 38, 657-664. [CrossRef] [PubMed]

55. Matthews, H.S.; Hendrickson, C.T.; Weber, C.L. The importance of carbon footprint estimation boundaries. Environ. Sci. Technol. 2008, 42, 5839-5842. [CrossRef] [PubMed] 
56. Lenzen, M. Errors in Conventional and Input-Output-Based Life-Cycle Inventories. J. Ind. Ecol. 2001, 4, 127-148. [CrossRef]

57. Fuller, R.J.; Crawford, R.H. Impact of past and future residential housing development patterns on energy demand and related emissions. J. Hous. Built Environ. 2011, 26, 165-183. [CrossRef]

58. Polasky, S.; Carpenter, S.R.; Folke, C.; Keeler, B. Decision-making under great uncertainty: Environmental management in an era of global change. Trends Ecol. Evol. 2011, 26, 398-404. [CrossRef] [PubMed]

59. Säynäjoki, A. How Does the Construction of a Residential Area Contribute to Climate Change? - Timing Reveals New Perspectives to Climate Change Mitigation; Aalto University: Espoo, Finland, 2015.

(C) 2016 by the authors; licensee MDPI, Basel, Switzerland. This article is an open access article distributed under the terms and conditions of the Creative Commons Attribution (CC-BY) license (http://creativecommons.org/licenses/by/4.0/). 